Military Technical College Kobry El-Kobbah, Cairo, Egypt

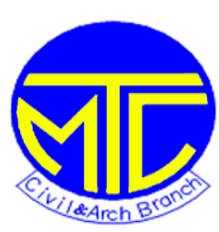

$12^{\text {th }}$ International Conference on Civil and Architecture Engineering ICCAE-12-2018

\title{
IDENTIFICATION AND ANALYSIS OF MAIN REASONS OF VARIATION ORDERS AND THEIR IMPACTS DURING CONSTRUCTION PROJECT LIFE CYCLE
}

\author{
Hasan A. Thani ${ }^{(1)}$, Mohamed E. Saleh ${ }^{(2)}$, Nabil H. Amer ${ }^{(3)}$
}

\begin{abstract}
Variation Orders in construction are often be accompanied with series of impacts on the quality, time, and cost of the projects. This issue requires proper analysis and action to develop quantitative methods to measure the reasons and effects of variation orders and make a complete assessment for them. This paper presents a study of the most important factors which are considered to have an impact on the time and the cost of the project during its life cycle stages for various governmental construction projects done in the Kingdom of Bahrain. The construction projects were in particular buildings, warehouses, facilities and government buildings with a contractual value of about 18.6 million US dollars.

Those two dimensions of the variation orders (cost, time) are applied to these specific factors: Owner, Consultant, Contractor, Project Management, Local Authorities, and Force Majeure.Using questionnaire survey, replies received from 43 participants specialized in construction industry and various government and private sectors on the causes and effects of project changesto analyze the RISK significance index. The RISK significance indexindicates and sorts the most effective reasons causing variation orders.
\end{abstract}

The results of the above mentioned analysisshowthat the owner is responsible for the most variation orders generated, and that the owner financial difficulties during construction stage has the most value of RISK significance index.

Keywords -Variation order; Impact; Cost;Time; RISK significance index.

(1) Hasan A. Thani, M.S. candidate, Bahrain Defence Force HQ, Bahrain.

(2) Mohammed E. Saleh,Doctor,Engineering Authority of Egyptian Armed Force, Egypt.

(3) Nabil H. Amer, Assistant Prof, Military Technical Collage, Cairo, Egypt. 


\section{INTRODUCTION}

Variation is as any alteration or modification of the design, quality or quantity of the Works, includes additions, omissions or substitutions [1]. Also variation order can be defined as administrative process to compensate a contractor for additional costs on a construction project. It is an instrument prepared by the engineer and signed by the owner, contractors, and engineer, each stating their agreement to any/all of the following: change(s) in work; the amount of the adjustment,if any, in the contract sum; and the extent of the adjustment, if any, in the contract time [2].

The most widely experienced impacts and effects result from variation orders are extension of execution time, and alter in cost of work. In addition to that, variation orders can be the source of dispute between project participants and lead to quality and productivity degeneration.

All of those mentioned effects have prompted researchers to study and analyze the reasons behind the variation orders, then develop measurement tools to quantitate the impact of variation orders to understand the true magnitude of the impact.

(Leonard C, 1988) investigated 90 cases of variation orders and obtained that the design errors and omissions are responsible of $65 \%$ of variation orders, $30 \%$ of variation orders related to design changes, and 5\% due to unforeseen conditions [3]. (Hasegawa K, 1995) reported 7 reasons of change order occurrence referred to client request, overall criteria change, design efficiency, design errors and omissions, an additive bid item, unforeseen condition encountered, and initiated value engineering [4]. (Arain F, 2005) identified new reasons have arisen due to the revolutionary development in the field of constructions, such as: design complexity, lack of skilled manpower and professionals, and logistics delay [5]. (Mohammed Saleh, 2012) summarized and categorized 35 reasons of variation orders associated with sports construction facilities attributed them to the construction projects members (Owner, Consultant, Contractor, project management team, Local authorities, and force majeure) [6].

Causes of variation orders Attributed to the Construction Project Parties:

A. Variation orders attributed to the Owner:

1. Additional client request during the course of the project.

2. Stopped, disrupted or interrupted work.

3. Owner Financial difficulties.

4. Accelerated performance requested by the owner.

5. Delays from the owner's acts.

6. Initiated value engineering change.

B. Variation orders attributed to the Designer/ Consultant:

1. Design revisions (change).

2. Design errors or omissions.

3. Design deficiency .

4. Insufficient details in the plans and specifications.

5. Unanticipated works.

6. Discrepancies in the contract drawings.

7. Unavailable specified products.

8. Incomplete scope definitions. 
9. Over inspection.

10. Differing site conditions.

11. Work method restrictions.

C. Variation orders attributed to the Contractor:

1. Construction errors.

2. Construction omissions.

3. Remedial work.

4. Work out of sequence.

5. Material \& equipment late delivery.

6. Following new or different schedule.

7. Contractor Financial Difficulties.

8. Lack of skilled labor.

9. Increased Risks.

D. Variation orders attributed to Project Management:

1. Lack of Coordination.

2. Difference in contract interpretation.

3. Errors in contract documents.

E. Variation orders attributed to Local Authorities:

1. Third party permits.

2. Governmental actions.

3. Restrictions in site access.

4. Utility relocation.

F. Variation orders attributed to Force Majeure:

1. Unexpected Events.

2. Nature and human acts.

By using a questionnaire survey targeted the experts in the field of construction, a database to address the variation orders in construction projects were developed which provides a foundation upon recommendations aimed to reduce variation orders costs.

In this paper, an effort was made to list the top 20 reasons of variation orders, which have great impact on cost and time of construction projects in point of view of the experts. The owner financial difficulties was on the top of the list.The study also found that owner is the most project party responsible for generating variation orders. Furthermore, the study identify the top reasons of variation orders according to each project party.

\section{RESEARCH SCOPE AND OBJECTIVES}

After the decline in crude oil prices, the Gulf Cooperation Council (GCC) countries, which rely heavily on oil resources, have resorted to austerity measures and economic policies to diversify sources of income, to develop the local economy and to increase the Gross Domestic Product (GDP). 
In this regard, the Kingdom of Bahrain has taken many measures, including examining the reasons for the financial increases in construction projects, analyzing these reasons and finding suitable solutions to reduce these costs.

This vision has set us the objectives of this reasearch paper as follows:

- To identify the most important causes which lead to variation orders occurrence in construction projects.

- To determine the degree of importance for each cause.

- To rank this improved list according to some factors such as frequency of occurrence, impact on labor productivity, cost and time, to realize the most effective causes of variation orders in construction industry.

\section{REASEARCH METHODOLGY}

The method used in this research is to benefit from previous experiences and studies in the field of study and analysis of the causes and effects of change orders on construction projects and then to employ and modify them to suit the study environment and to find mathematical models to analyse these causes and effects.

\section{III.1 SAMPLE DESIGN}

The number of interviews has to be conducted to obtain reasonable values was computed using statistical equation of determining sample size for the estimation of mean, as follows:

$$
N=Z^{2} O^{2} / E^{2}
$$

Where,

$N$ : The sample size (The minimum number of questionnaire required).

$Z^{2}$ : The value corresponding to the level of confidence.

$O^{2}$ : The standard deviation.

$E^{2}$ : The maximum error.

The calculated sample standard deviation $(O)$ was take from random interview, and the value of $O$ was 0.147 . Furthermore, The $\mathrm{Z}$ value according to a level of confidence of $95 \%$ is 1.96 and maximum error were set to 0.05 . From this we can calculate the minimum number of questionnaires to be distributed, as follows:

$$
\mathrm{N}=(1.96)^{2}(0.147)^{2} /(0.05)^{2} \approx 33 \text { questionnaire }
$$

\section{III.2 SURVEY QUESTIONNAIRE}

A survey study was conducted in which 43 participants were involved in the field of construction to determine the frequency of these reasons and the direct impact on the time, money, quality and progress of work in the different stages of the construction project. A total of 60 questionnaires were distributed in the Kingdom of Bahrain and the Arab Republic of Egypt, as well as some foreign construction companies that are based in the GCC countries. The number of responses received was 43 , constituting $72 \%$ of the total number of questionnaires. 
The questionnaire was divided in two parts. The first part relates to the general information of the participants and the industrial characteristics of their organization,to obtain statistical information to identify the quality of the study sample used in this research paper.

The second part examines the frequency of occurrence of the cause and its probability, and linked them by using the RISK significant index which developed by (Shen, 2001) [7], to obtain the significance score for each reason of variation orders in order to rank them.

\section{III.3 DATA ANALYSIS METHOD}

By using the RISK significance index which developed by (Shen, 2001). The significance score for each cause of variation orders assessed by each respondent can be calculated through:

$$
S_{i j}=\alpha_{i j} \times \beta_{i j}
$$

Where,

$S_{i j}$. The significance score of cause of change order $\left(_{i}\right)$ as acknowledged by respondent $\left(_{j}\right)$.

$\alpha_{i j}$. The probability of occurrence for cause of change order $\left.{ }_{i}\right)$ as acknowledged by respondent $\left({ }_{j}\right)$.

$\beta_{i j:}$ the degree of impact for a cause of change order $\left({ }_{i}\right)$ as acknowledged by respondent $\left({ }_{j}\right)$.

Thus,

$$
R S I S_{i}=\Sigma S_{i j} / N
$$

Where,

$R S I S_{i}$ : the relative significance index scorefor cause of change order $\left({ }_{i}\right)$.

$\Sigma S_{i j:}$ The significance score of cause of change order $\left({ }_{i}\right)$ as acknowledged by respondent $\left.{ }_{j}\right)$.

$\mathrm{N}$ : The number of respondents.

To convert the data into arithmetic outputs, the probability of occurrence $(\alpha)$ of the cause was converted to three-point scale as follows: (High $=1$, Moderate $=0.5$, Low $=0.1$ ), the degree of impact of the cause $(\beta)$ on the project was also converted to a five-point scale as follows: (Very High $=1$, High $=0.8$, Moderate $=0.6$, Low $=0.4$, Very Low $=0.2$ ), according to those scales, a matrix for the calculation of the RISK significance index is illustrated in Table 1.

TABLE 1

MATRIX OF THE RISK SIGNIFICANCE INDEX

\begin{tabular}{|l|ccccc|}
\hline$\alpha$ & $\begin{array}{c}\text { Very } \\
\text { High } \\
(1)\end{array}$ & $\begin{array}{c}\text { High } \\
(0.8)\end{array}$ & $\begin{array}{c}\text { Moderate } \\
(0.6)\end{array}$ & $\begin{array}{c}\text { Low } \\
(0.4)\end{array}$ & $\begin{array}{c}\text { Very } \\
\text { Low } \\
(0.2)\end{array}$ \\
\hline High (1) & 1 & 0.8 & 0.6 & 0.4 & 0.2 \\
Moderate (0.5) & 0.5 & 0.4 & 0.3 & 0.2 & 0.1 \\
Low (0.1) & 0.1 & 0.08 & 0.06 & 0.04 & 0.02 \\
\hline
\end{tabular}




\section{SURVEY FINDINGS AND RESULTS}

Data were analysed using the Statistical Package for Social Sciences (SPSS) and Microsoft Excel (MS Excel) to rank the causes of variation orders based on their Relative Significance Index Score (RSIS).

\section{IV.1 GENERAL INFORMATION}

There were 43 experts participated in the survey, $54 \%$ of the participants are project managers, $35 \%$ are quantity surveyor, and $11 \%$ are site engineers. Figure 1 illustrates the job position of the participants.

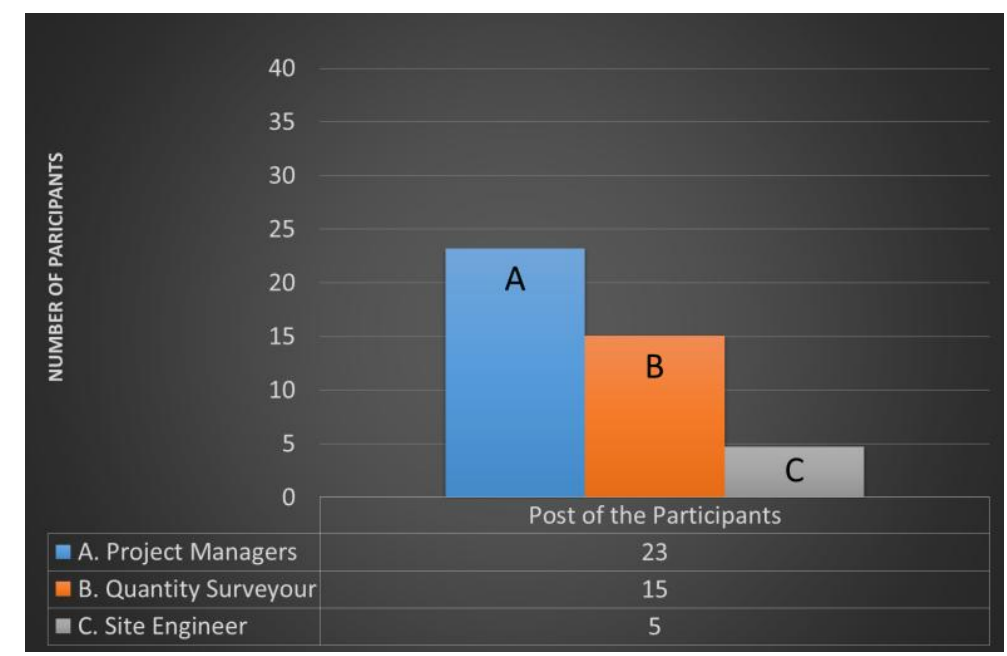

Fig. 1 Job position of the participants

As for the role of the organizations which participated in this survey $14 \%$ of the participants belong to organizations representing the owner, $19 \%$ of the participants are consultants, $49 \%$ as contractors and only $2 \%$ as sub-contractors, while $16 \%$ of the participants belong to organizations play more than one role in the construction projects. Figure 2 illustrates the role of the participated organizations.

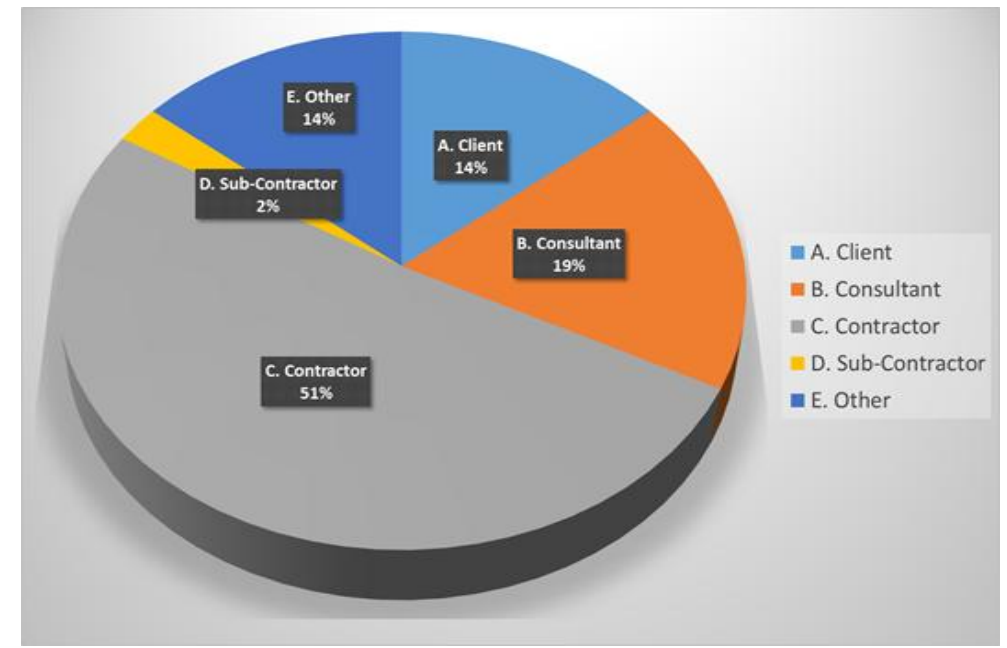

Fig. 2 The role of the organizations

The number of participants representing the government sectors was 21 , while the number of representatives of the private sector was 22 . Figure 3 illustrates the type of the organization sector. 


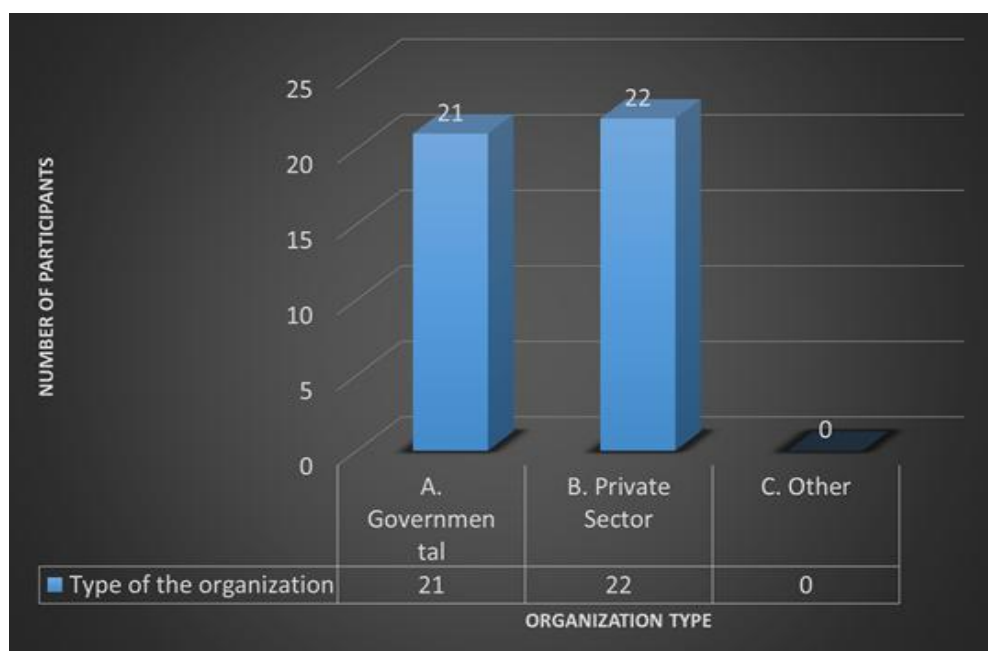

Fig. 3 The type of the organizations sector

The nationalities of the organizations that participated in the survey were mostly Bahrainis and represented $81 \%$, the foreign organization came in the second place with $12 \%$ and finally the Egyptian organizations represented $7 \%$ of the participants. Figure 4 illustrates the nationality of the participated organizations.

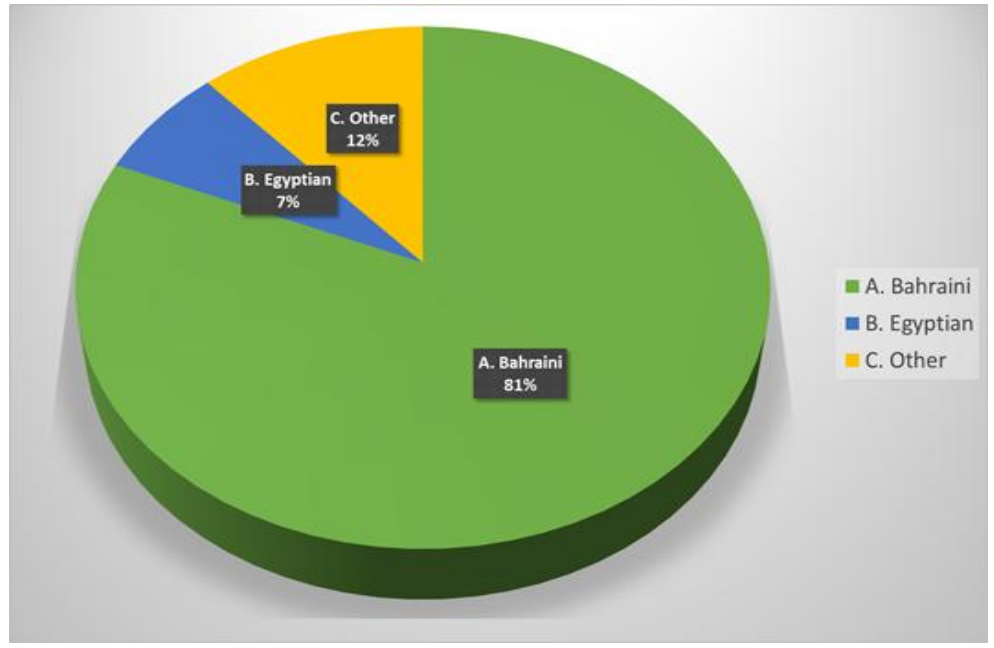

Fig. 4 The nationality of the organization

In addition, participants were also counted and sorted according to the following items:

- Size of the organizations.

- Experience of organizations.

- Industrial characteristics of the organizations:

A. Projects value.

B. Duration of the projects.

C. Percentage of cost increment in the projects due to variation orders.

D. Percentage of time increment in the projects due to variation orders. 
E. The prime originator of variation orders in projects.

F. Type of construction procurement contract used in the projects.

G. Project documentation format.

H. Tender awarding system.

I. Number of bidders participated in the projects.

J. Financial compensation method for variation orders.

K. Percentage of sub-contracted work.

L. Types of variations proceed without approval.

M. Number of approvals to proceed variation orders.

$\mathrm{N}$. Time required to process variation orders.

$\mathrm{O}$. The relationship level between project parties.

P. Assignation of the project management team for the projects.

Q. The project stage which is the most involvement by the owner.

R. Primary driving factor in the projects.

S. Activities that generate the most variation orders in projects.

\section{IV.2 VARIATION ORDERS CAUSES AND EFFECTS}

By analyzing the results of the survey, the most influential reasons were reached from the point of view of the experts, leading to an increase in cost of the construction projects as well as the duration of the implementation of the construction project, as follows:

\section{IV.2.1 VARIATION ORDERS CAUSES ATTRIBUTED TO THE OWNER}

The top three variation orders causes attributed to the owner were, owner financial difficulties during construction stage, delay from the owner acts during construction stage, and additional requirements by the owner through construction stage. That means the variation orders which arise during construction stage have more impact on the project the other stages. The top three variation orders causes attributed the owner are illustrated in Table 2 and Figure 5.

TABLE 2

TOP THREE VARIATION ORDERS CAUSES ATTRIBUTED THE OWNER

\begin{tabular}{|c|llcc|}
\hline Ser. & \multicolumn{1}{|c}{ Factor } & $\begin{array}{c}\text { Project Life } \\
\text { Cycle }\end{array}$ & $\begin{array}{c}\text { Average } \\
\text { RSIS }\end{array}$ & $\begin{array}{c}\text { Standard } \\
\text { deviation }\end{array}$ \\
\hline $\mathbf{1}$ & Owner Financial difficulties & Construction & 0.40 & 0.35 \\
$\mathbf{2}$ & $\begin{array}{l}\text { Delays from owner's acts } \\
\mathbf{3}\end{array}$ & $\begin{array}{l}\text { Construction } \\
\text { Additional requirements by }\end{array}$ & 0.38 & 0.34 \\
& client & Construction & 0.38 & 0.30 \\
\hline
\end{tabular}




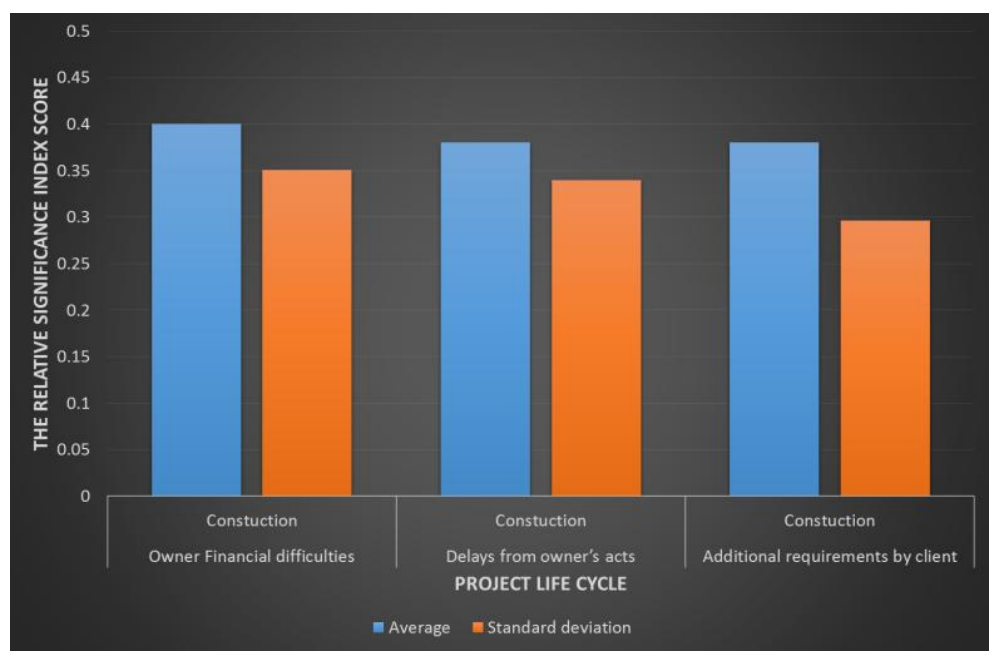

Fig. 5 Top three variation orders causes attributed the owner

\section{IV.2.2 VARIATION ORDERS CAUSES ATTRIBUTED TO THE CONSULTANT}

The top three variation orders causes attributed to the consultant were insufficient details in the plans and specifications during planning/estimation/design stage then during construction stage, and design revision through construction stage. It is noticeable that the variations that appear during the planning and construction stage are very significant due to causes attributed to the consultant. The top three variation orders causes attributed the consultant are illustrated in Table 3 and Figure 6.

TABLE 3

TOP THREE VARIATION ORDERS CAUSES ATTRIBUTED THE CONSULTANT

\begin{tabular}{|c|lllcc|}
\hline Ser. & \multicolumn{1}{|c}{ Factor } & $\begin{array}{c}\text { Project Life } \\
\text { Cycle }\end{array}$ & $\begin{array}{c}\text { Average } \\
\text { RSIS }\end{array}$ & $\begin{array}{c}\text { Standard } \\
\text { deviation }\end{array}$ \\
\hline $\mathbf{1}$ & $\begin{array}{l}\text { Insufficient details in the } \\
\text { plans and specifications }\end{array}$ & $\begin{array}{l}\text { Planning/Esti } \\
\text { mation/Desig } \\
\mathrm{n}\end{array}$ & 0.40 & 0.34 \\
$\mathbf{2}$ & $\begin{array}{l}\text { Insufficient details in the } \\
\text { plans and specifications }\end{array}$ & Construction & 0.39 & 0.35 \\
$\mathbf{3}$ & $\begin{array}{l}\text { Design revisions(change) } \\
\text { Denstruction }\end{array}$ & 0.38 & 0.29 \\
\hline
\end{tabular}




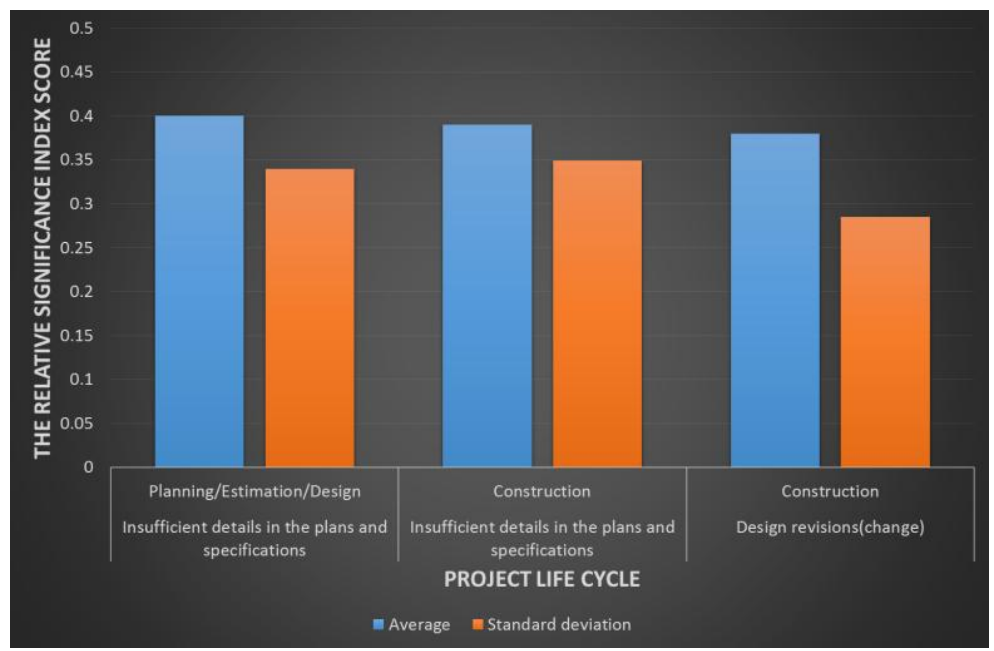

Fig. 6 Top three variation orders causes attributed the consultant

\section{IV.2.3 VARIATION ORDERS CAUSES ATTRIBUTED TO THE CONTRACTOR}

The top three variation orders causes attributed to the contractor were contractor financial difficulties during construction stage, materials \& equipment late delivery during construction stage, and contractor financial difficulties at hand over stage. Hence it turns out the construction and hand over variations have great impact on cost and time due to causes attributed to the contractor. The top three variation orders causes attributed the owner are illustrated in Table 4 and Figure 7.

\section{TABLE 4}

TOP THREE VARIATION ORDERS CAUSES ATTRIBUTED THE CONTRACTOR

\begin{tabular}{|c|c|c|c|c|}
\hline Ser. & Factor & $\begin{array}{l}\text { Project Life } \\
\text { Cycle }\end{array}$ & $\begin{array}{l}\text { Average } \\
\text { RSIS }\end{array}$ & $\begin{array}{l}\text { Standard } \\
\text { deviation }\end{array}$ \\
\hline 1 & $\begin{array}{l}\text { Contractor financial } \\
\text { difficulties }\end{array}$ & Construction & 0.37 & 0.33 \\
\hline 2 & $\begin{array}{l}\text { Materials \& equipment late } \\
\text { delivery }\end{array}$ & Construction & 0.37 & 0.28 \\
\hline 3 & $\begin{array}{l}\text { Contractor financial } \\
\text { difficulties }\end{array}$ & $\begin{array}{l}\text { Hand } \\
\text { over/Closing }\end{array}$ & 0.36 & 0.36 \\
\hline
\end{tabular}




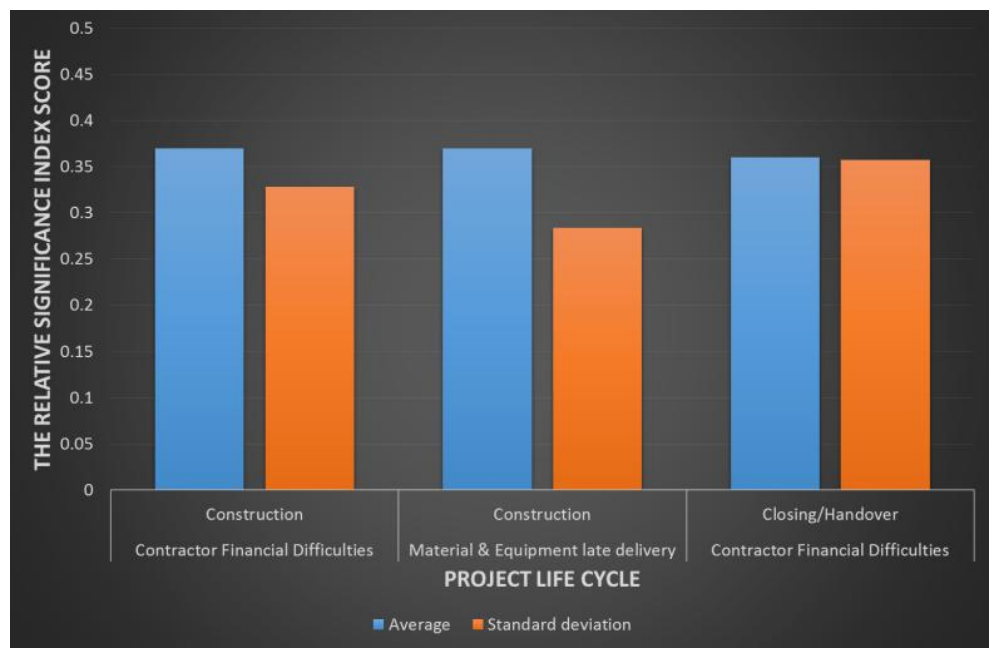

Fig. 7 Top three variation orders causes attributed the contractor

\section{IV.2.4 VARIATION ORDERS CAUSES ATTRIBUTED TO THE PROJECT MANAGEMENT}

The top three variation orders causes attributed to the project management team were lack of coordination between project team in both construction and hand over stage, and the errors in contract documents in planning/estimation/design stage. The top three variation orders causes attributed the owner are illustrated in Table 5 and Figure 8.

\section{TABLE 5}

TOP THREE VARIATION ORDERS CAUSES ATTRIBUTED THE PROJECT MANAGEMENT TEAM

\begin{tabular}{|c|llcc|}
\hline Ser. & \multicolumn{1}{|c}{ Factor } & $\begin{array}{c}\text { Project Life } \\
\text { Cycle }\end{array}$ & $\begin{array}{c}\text { Average } \\
\text { RSIS }\end{array}$ & $\begin{array}{c}\text { Standard } \\
\text { deviation }\end{array}$ \\
\hline $\mathbf{1}$ & Lack of coordination & Construction & 0.33 & 0.27 \\
$\mathbf{2}$ & Lack of coordination & $\begin{array}{l}\text { Hand } \\
\text { over/Closing }\end{array}$ & 0.26 & 0.28 \\
$\mathbf{3}$ & Errors in contract documents & $\begin{array}{l}\text { Planning/Est } \\
\text { imation/Desi } \\
\text { gn }\end{array}$ & 0.24 & 0.23 \\
\hline
\end{tabular}




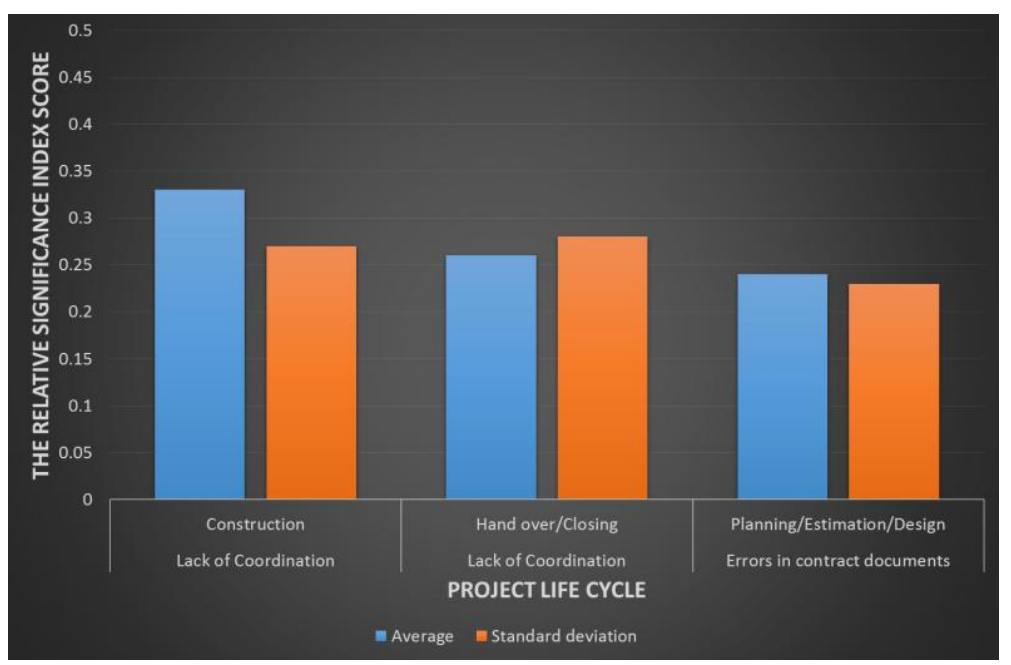

Fig. 8 Top three variation orders causes attributed the project management team

\section{IV.2.5 VARIATION ORDERS CAUSES ATTRIBUTED TO THE LOCAL AUTHORITIES}

The top three variation orders causes attributed to the local authorities were restriction in site access during construction stage, and delay in governmental permits during both planning/estimation/design stage and hand over stage. The top three variation order cause attributed the local authorities are illustrated in Table 6 and Figure 9.

\section{TABLE 6}

TOP THREE VARIATION ORDERS CAUSES ATTRIBUTED THE LOCAL AUTHORITIES

\begin{tabular}{|c|llcc|}
\hline Ser. & \multicolumn{1}{|c}{ Factor } & $\begin{array}{c}\text { Project Life } \\
\text { Cycle }\end{array}$ & $\begin{array}{c}\text { Average } \\
\text { RSIS }\end{array}$ & $\begin{array}{c}\text { Standard } \\
\text { deviation }\end{array}$ \\
\hline $\mathbf{1}$ & Restriction in site access & Construction & 0.27 & 0.26 \\
$\mathbf{2}$ & $\begin{array}{l}\text { Delay in governmental } \\
\text { permits }\end{array}$ & $\begin{array}{l}\text { Planning/Est } \\
\text { imation/Desi } \\
\text { gn }\end{array}$ & 0.24 & 0.24 \\
$\mathbf{3}$ & $\begin{array}{l}\text { Delay in governmental } \\
\text { permits }\end{array}$ & $\begin{array}{l}\text { Hand } \\
\text { over/Closing }\end{array}$ & 0.22 & 0.24 \\
\hline
\end{tabular}




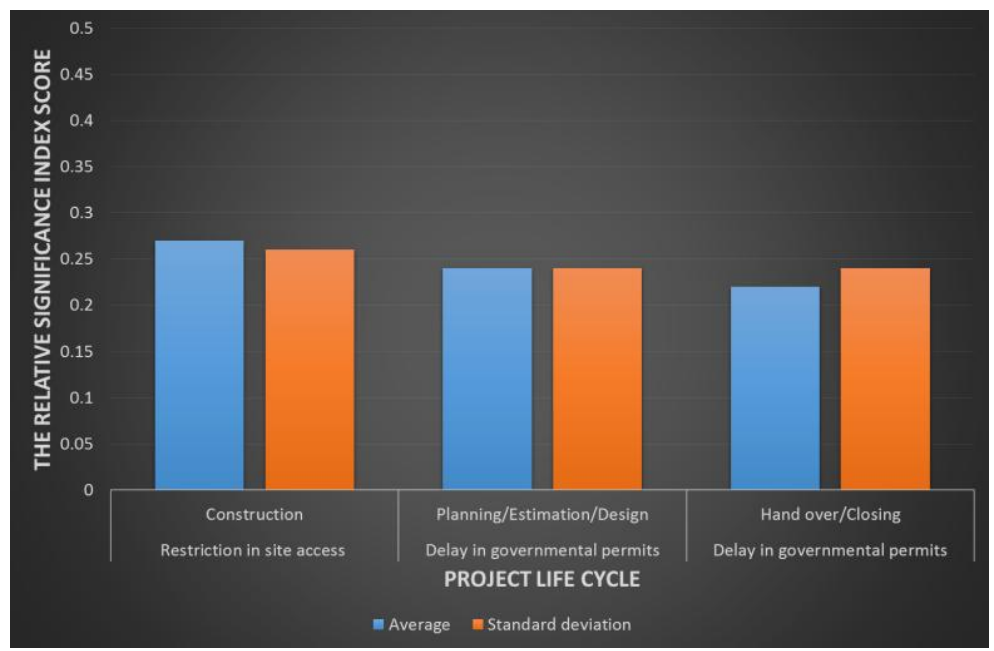

Fig. 9 Top three variation orders causes attributed the local authorities

\section{IV.2.6 VARIATION ORDERS CAUSES ATTRIBUTED TO THE FORCE MAJEURE}

The top three variation orders causes attributed to the force majeure were (strikes, riots, crimes, wars, and revolutions) during both construction and handover stage, and nature acts during construction stage. The top three variation order cause attributed the force majeure are illustrated in Table 7 and Figure 10.

\section{TABLE 7}

TOP THREE VARIATION ORDERS CAUSES ATTRIBUTED THE FORCE MAJEURE

\begin{tabular}{|c|llcc|}
\hline Ser. & \multicolumn{1}{|c}{ Factor } & $\begin{array}{c}\text { Project Life } \\
\text { Cycle }\end{array}$ & $\begin{array}{c}\text { Average } \\
\text { RSIS }\end{array}$ & $\begin{array}{c}\text { Standard } \\
\text { deviation }\end{array}$ \\
\hline $\mathbf{1}$ & $\begin{array}{l}\text { strikes, riots, crimes, wars, } \\
\text { and revolutions }\end{array}$ & Construction & 0.27 & 0.34 \\
$\mathbf{2}$ & $\begin{array}{l}\text { strikes, riots, crimes, wars, } \\
\text { and revolutions }\end{array}$ & $\begin{array}{l}\text { Hand } \\
\text { over/Closing }\end{array}$ & 0.23 & 0.31 \\
$\mathbf{3}$ & Nature acts & Construction & 0.16 & 0.21 \\
\hline
\end{tabular}




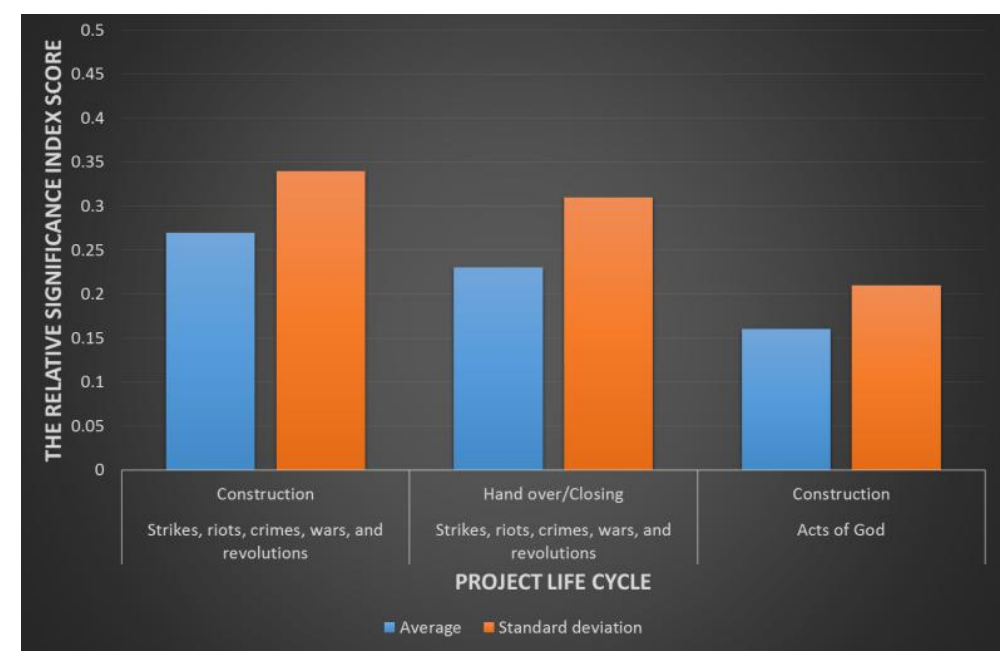

Fig. 10 Top three variation orders causes attributed the force majeure

\section{IV.2.7 TOP TWENTY CAUSES OF VARIATION ORDERS ATTRIBUTED TO THE PROJECT PARTIES}

In the questionnaire, we identified the top twenty causes for the variation orders which have great impact on both cost and time and included it in Table 8. These causes were arranged in descending orders according to the average RSIS for each cause through different stages of PCL (Project life Cycle). The top twenty causes for the variation are illustrated in Table 8 and Figure 11.

Form table 8, we can conclude that he top five variation orders causes were owner financial difficulties during construction stage, insufficient details in the plans and specifications during planning/estimation/design stage, insufficient details in the plans and specifications during construction stage, delays from owner's acts during construction stage, and additional requirements by client during construction stage. 
TABLE 8

TOP TWENTY CAUSES OF VARIATION ORDERS ATTRIBUTED TO PROJECT PARTIES BASED ON THEIR AVERAGE RSIS

\begin{tabular}{|c|c|c|c|c|}
\hline Ser. & Factor & Project Life Cycle & $\begin{array}{l}\text { Average } \\
\text { RSIS }\end{array}$ & $\begin{array}{l}\text { Standard } \\
\text { deviation }\end{array}$ \\
\hline 1 & Owner Financial difficulties & Construction & 0.40 & 0.35 \\
\hline 2 & $\begin{array}{l}\text { Insufficient details in the plans and } \\
\text { specifications }\end{array}$ & $\begin{array}{l}\text { Planning/Estimatio } \\
\mathrm{n} / \text { Design }\end{array}$ & 0.40 & 0.34 \\
\hline 3 & $\begin{array}{l}\text { Insufficient details in the plans and } \\
\text { specifications }\end{array}$ & Construction & 0.39 & 0.35 \\
\hline 4 & Delays from the owner's acts & Construction & 0.38 & 0.34 \\
\hline 5 & Additional requirements by client & Construction & 0.38 & 0.30 \\
\hline 6 & Design revisions(change) & Construction & 0.38 & 0.29 \\
\hline 7 & Contractor Financial Difficulties & Construction & 0.37 & 0.33 \\
\hline 8 & Material \& Equipment late delivery & Construction & 0.37 & 0.28 \\
\hline 9 & Contractor Financial Difficulties & Hand over/Closing & 0.36 & 0.36 \\
\hline 10 & Stopped, disrupted or interrupted work & Construction & & 0.34 \\
\hline 11 & Owner Financial difficulties & Hand over/Closing & 0.33 & 0.34 \\
\hline 12 & $\begin{array}{l}\text { Accelerated performance requested by } \\
\text { the owner }\end{array}$ & Hand over/Closing & 0.33 & 0.32 \\
\hline 13 & Following new or different schedule & Construction & 0.33 & 0.31 \\
\hline 14 & Lack of Coordination & Construction & 0.33 & 0.27 \\
\hline 15 & $\begin{array}{l}\text { Accelerated performance requested by } \\
\text { the owner }\end{array}$ & Construction & 0.33 & 0.27 \\
\hline 16 & Delays from the owner's acts & Hand over/Closing & 0.32 & 0.36 \\
\hline 17 & Design errors or omissions & Construction & 0.32 & 0.31 \\
\hline 18 & Lack of skilled labor & Construction & 0.32 & 0.29 \\
\hline 19 & Delays from the owner's acts & $\begin{array}{l}\text { Planning/Estimatio } \\
\text { n/Design }\end{array}$ & 0.30 & 0.33 \\
\hline 20 & Design revisions (change) & $\begin{array}{l}\text { Planning/Estimatio } \\
\mathrm{n} / \text { Design }\end{array}$ & 0.30 & 0.27 \\
\hline
\end{tabular}




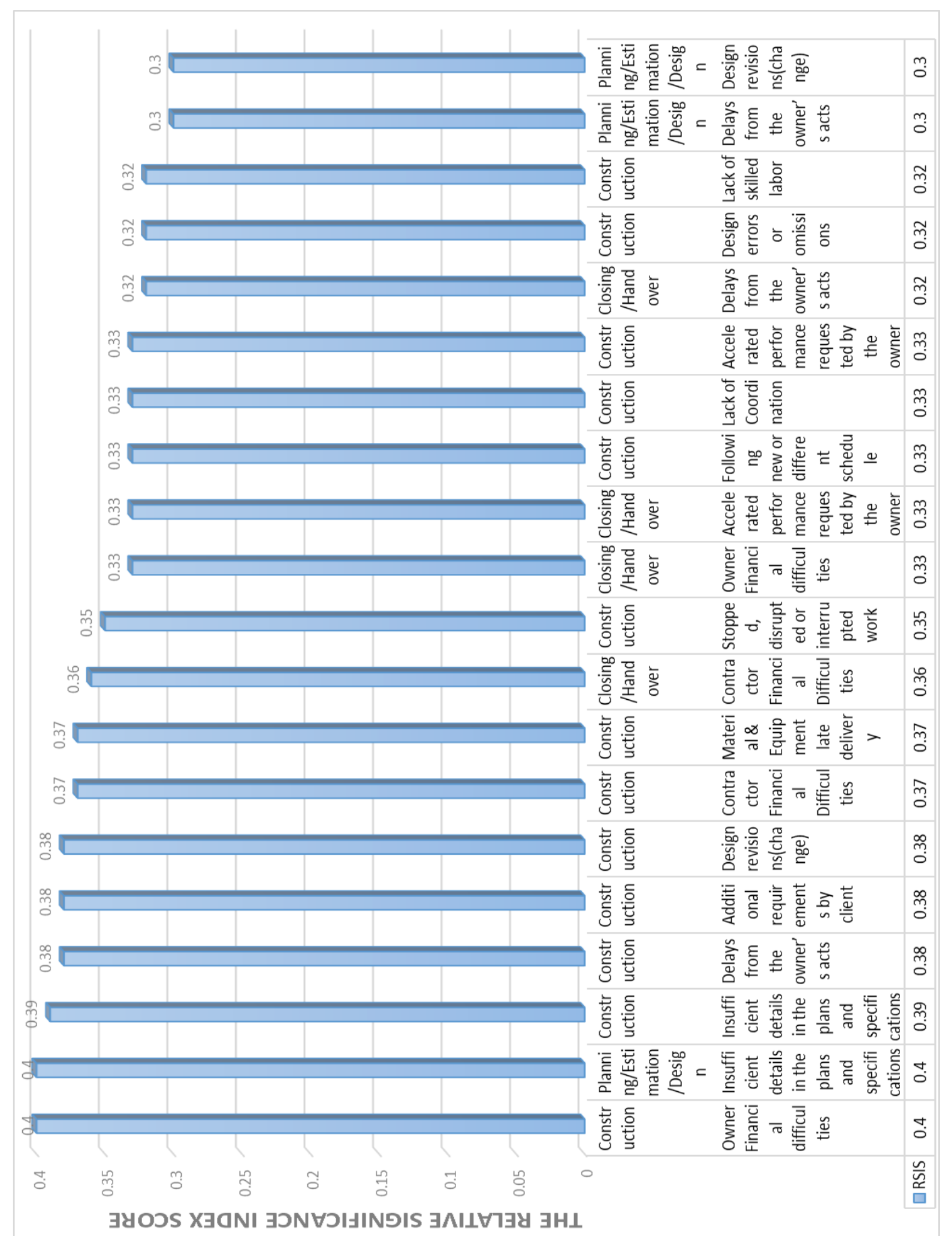

Fig. 11 Top twenty causes of variation orders attributed to the project parties 


\section{IV.2.8 CAUSES OF VARIATION ORDERS ACCORDING TO PROJECT LIFE CYCLE}

From the above it was observed that the causes of variation order which generated during construction stage had the most influential effect on cost and time in construction project, after that hand over/closing stage came on second place, and finally the stage of planning/estimation/design came at last. The RSIS of the stages during PCL are presented in table 9 and figure 12.

TABLE 9

THE RSIS OF THE STAGES DURING PCL

\begin{tabular}{|c|lcc|}
\hline Ser. & Project Life Cycle & $\begin{array}{c}\text { Average } \\
\text { RSIS }\end{array}$ & Standard deviation \\
\hline $\mathbf{1}$ & Construction & 0.36 & 0.31 \\
$\mathbf{2}$ & Hand over/Closing & 0.34 & 0.32 \\
$\mathbf{3}$ & $\begin{array}{l}\text { Planning/Estimation/ } \\
\text { Design }\end{array}$ & 0.33 & 0.30 \\
\hline
\end{tabular}

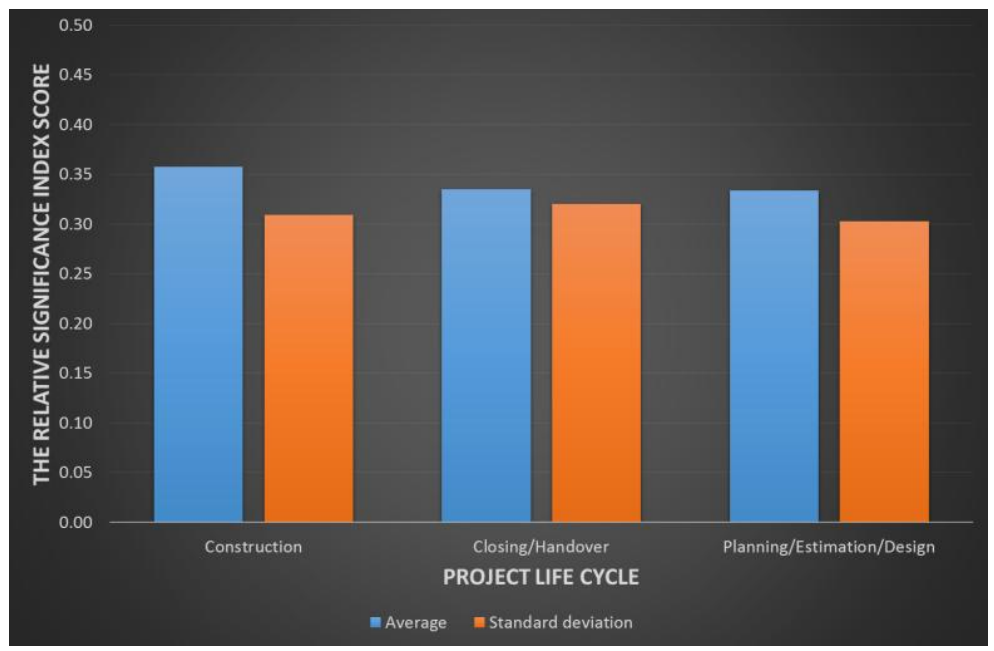

Fig. 12 The RSIS of the stages during PCL

\section{IV.2.9 RESPONSIBILITY FOR CAUSES OF VARIATION ORDERS}

The most frequently and costly variation orders were generated due to changes attributed to the owner as per this study, while the effects of the causes attributed to the consultant, contractor, and project management are equally came in the second place, causes attributed to the local authorities ranked as third, and finally the cause attributed to the force majeure. Table 10 and figure 13 presents the RSIS of responsibility for variation orders causes. 
TABLE 10

THE RSIS OF RESPONSIBILITY FOR VARIATION ORDERS CAUSES

\begin{tabular}{|c|lccc|}
\hline Ser. & $\begin{array}{l}\text { Responsible for variation } \\
\text { orders }\end{array}$ & $\begin{array}{c}\text { Average } \\
\text { RSIS }\end{array}$ & $\begin{array}{c}\text { Standard } \\
\text { deviation }\end{array}$ & $\begin{array}{c}\text { \% of total } \\
\text { RSIS }\end{array}$ \\
\hline 1 & Owner & 0.28 & 0.28 & $21 \%$ \\
& & & & \\
2 & Consultant & 0.23 & 0.25 & $17 \%$ \\
& Contractor & 0.22 & 0.30 & $17 \%$ \\
& $\begin{array}{l}\text { Project Management } \\
\text { team }\end{array}$ & 0.22 & 0.25 & $17 \%$ \\
3 & Local Authorities & 0.19 & & \\
4 & Force Majeure & 0.18 & 0.25 & $15 \%$ \\
\hline
\end{tabular}

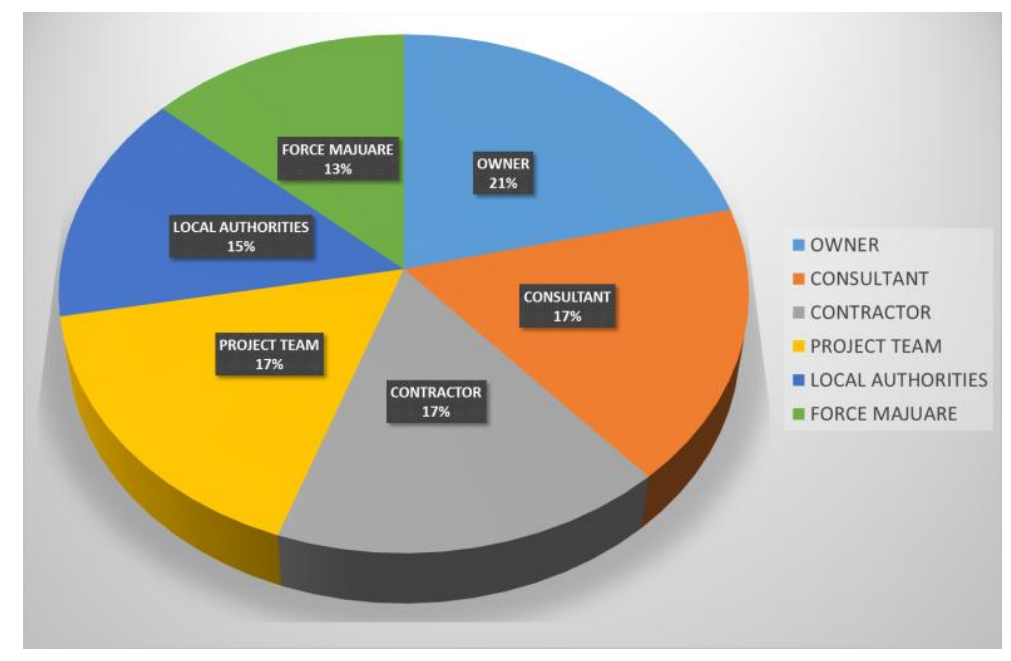

Fig. 13 The responsibility for variation orders causes.

\section{CONCLUSIONS}

Conclusions that can be drawn from these findings are:

- Owner financial difficulties is the most significance cause of owner-related variation orders with average RSIS of 0.40 .

- Insufficient details in plans and specifications is the most significance cause of consultant-related variation orders with average RSIS of 0.40 .

- Contractor financial difficulties is the most significance cause of contractor-related variation orders with average RSIS of 0.37 .

- Lack of coordination is the most significance cause of project management team-related variation orders with average RSIS of 0.33 .

- Restriction in site access is the most significance cause of local authorities-related variation orders with average RSIS of 0.27 .

- Human acts (strikes, riots, wars, and revolutions) is the most significance cause of force majeurerelated variation orders with average RSIS of 0.27 . 
- Recognition of the top 20 causes of variation orders, tocontrol and manage the unwanted increases in cost and time of the construction project.

- Construction stage during the PCL is responsible for generating most of the causes of variation orders with average RSIS of 0.36 .

- The owner is responsible of $21 \%$ of causes of variation orders which is considered the highest percentage among project parties.

\section{REFERENCES}

[1] J. Murdoch and W. Hughes, "Payment" in Construction contracts: law and management, 3rd ed., Taylor \& Francis e-Library, 2001, pp. 200-207.

[2] AIA (1997) "General Conditions of the Contract for Construction," Document A201, American Institute of Architects, www.aiane.org/Info/documents/docSynopsis/synopsis-10.htm.

[3] C. A. Leonard, "The Effects of Change Orders on Productivity," M.S. thesis, Faculty of Engineering and Computer Science, Concordia University, Montreal, Quebec, Canada, 1988.

[4] K. Hasegawa," Pending Change/Modication Codes”, Internal PACDIV Pearl Harbor Construction Office Memorandum, 1995.

[5] Arain, F.M., "Strategic Management Of Variation Orders For Institutional Buildings: Leveraging On Information Technology", Proceedings of PMI Global Congress, Toronto,Canada, 2005.

[6] M.E. Saleh, "Effect of Change Order on the Construction Projects" Ph.D. dissertation, Faculty OF Engineering, Ain Shams University, Cairo, Egypt, 2012.

[7] L.Y. Shen, "Risk Assessment For Construction Joint Ventures In China" Journal of Construction engineering and management, ASCE, 127 (1), 76-81, 2001. 